\title{
SMART TOURISM CONCEPT IN SLOVAK MARKET CONDITIONS
}

\author{
Lukas Valko ${ }^{1}$ \\ Eva Smolkova ${ }^{2}$
}

DOI: https://doi.org/10.31410/ERAZ.2019.223

\begin{abstract}
Tourism is an integral part of Slovak economy. As current market conditions are continuously evolving, tourism had to undergo many changes. Many economical areas are currently under the huge influence of ICT sector and tourism is no exception. Main aim of this paper is to create an integrated theoretical base of the topic Smart Tourism. This paper includes a brief overview of Smart Tourism concept, complex definition of Smart Tourism and categorization of smart technology tools used in tourism. The last chapter is dedicated to Smart Tourism concept use in Bratislava, Slovakia. The paper may stand as a basis for further Smart Tourism analyses and for practical implementation this concept into praxis of organizations operating in tourism sector worldwide.
\end{abstract}

Keywords: tourism, smart, ICT, Slovakia

\section{INTRODUCTION}

$\mathrm{T}$ ourism plays a vital role in many developing and already developed countries as well. Some of them are critically dependent on this economical sector and thus is important to research it and support if needed. Help could be brought by ICT technology, simply called as smart technology. Smart technology is, considered in tourism, however, still quite a new factor, so there is no general guideline to its application and implementation. And this may be a challenge for some enterprises, because often a single wrong decision can lead to devastating consequences. And there are still many unanswered questions or unsolved queries which have to be researched in order to reach the full potential of Smart Tourism.

\section{2. “SMART TOURISM” DEFINITION}

Listed are three definitions of Smart Tourism:

- 'Individual tourist support system within the context of information services and an all-encompassing technology.' [1]

- ,The term (note: ,Smart') has been added to cities (i.e. smart city) to describe efforts aimed at using technologies innovatively to achieve resource optimization, effective and fair governance, sustainability and quality of life.' [2]

- ,Cloud computing, big data, mobile apps, location-based services, geo-tag services, beacon technology, virtual reality, augmented reality, and social networking services are all cutting-edge examples of smart technologies enhancing the tourism experiences and services.' [3]

\footnotetext{
1 Comenius University in Bratislava, Faculty of management, Odbojarov 10, P.O.BOX 95, 82005 Bratislava, Slovakia

2 Comenius University in Bratislava, Faculty of management, Odbojarov 10, P.O.BOX 95, 82005 Bratislava, Slovakia
} 
Lopez de Avila explains Smart Tourism as a set of several components supported by ICT. It connects these Smart's: experience, business ecosystem and destination (cities). The point is, that smart city principles do not consider only residents of a city and its surroundings, but tourists as well. Main aim of Smart Tourism is to increase the quality of mobility, resource availability/ allocation, quality of life/visit and sustainability. [4]

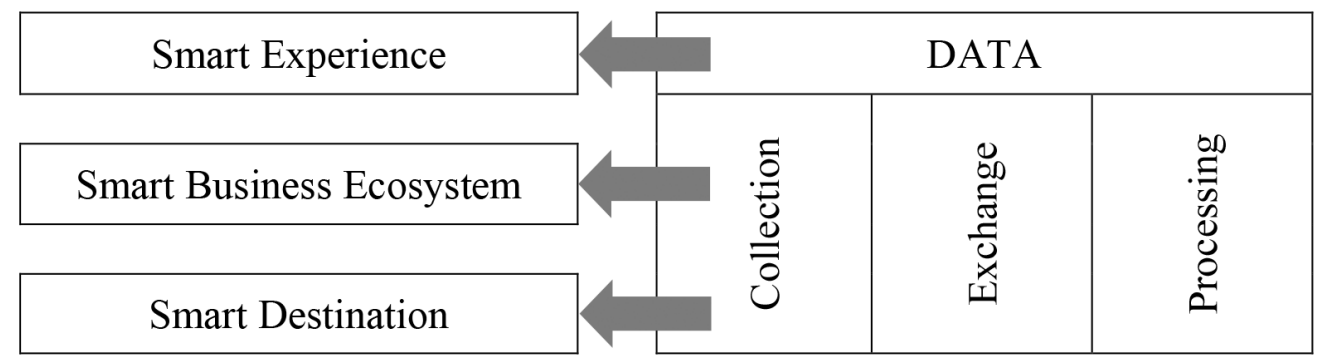

Figure 1: Components and layers of Smart Tourism [4]

Although high number of different definitions are available in literature, there is no such a definition which would fully unify the two sectors - Smart technology and Tourism. After reviewing several other interpretations of the term "Smart Tourism", we managed to create a single unifying definition which is compliant with all the essentials needed to be covered by intersection of these sectors:

"Smart Tourism is a style of offering tourism products, which integrates available smart technology into standard touristic experience, enables to measure tourism more effectively and provides tourist with innovative state-of-the-art solutions."

This Smart Tourism definition emphasizes the interconnection between smart technology and tourism, offers two-sided view of the topic and can provide a basis for future analyses and researches.

\section{SMART TOURISM SPECIFICATIONS}

Smart tourism is not a subgroup of tourism. Thus, we are not able to strictly say that it is on a lower level in the sector structure. Smart technology stands just as an enrichment of basic tourism and its role is to make tourism simpler and more attractive for customers. This is a customer-oriented function of Smart Tourism.

However, at the same time it enables companies to collect information about the customers and provide a basis for company decision-making. Collected data is today known as big data. And the sources of such data are mainly smart devices - phones, computers, GPS or the people themselves through their social media accounts, pictures or videos. [5] This is a data collecting function of Smart Tourism.

Due to W. C. Hunter, the aim of Smart Tourism is to build a sort of social ecosystem via information exchange, which is possible mainly through mobile devices with internet connection. [6] Therefore, we are able to say that smart technology in tourism is not only a tool for collecting data about where your customer currently is, or which products they are interested in. It has a deeper, social meaning and stands mainly as a tool which connects people with similar interests and/or in the same destination into one community. This is a social function of Smart Tourism. 
In the table below you can find main differences between standard tourism and Smart Tourism:

\begin{tabular}{|l|l|}
\hline Tourism & Smart Tourism \\
\hline $\begin{array}{l}\text { Standard procedures with standard tourism methods } \\
\text { and tools. }\end{array}$ & $\begin{array}{l}\text { Standard or brand-new procedures with innovative } \\
\text { tourism methods and tools. }\end{array}$ \\
\hline $\begin{array}{l}\text { Low rate of data collecting due to difficulty of } \\
\text { collecting processes. }\end{array}$ & $\begin{array}{l}\text { High rate of data collecting due to smart technology } \\
\text { availability. }\end{array}$ \\
\hline Is a part of the economy; produce income directly. & $\begin{array}{l}\text { Is only a middleman, enrichment of standard tourism; } \\
\text { does not stand as part of the economy and does not } \\
\text { produce income directly. }\end{array}$ \\
\hline $\begin{array}{l}\text { High number of different providers of different parts/ } \\
\text { stages of a travelling experience. }\end{array}$ & $\begin{array}{l}\text { Usually one subject, who provides the customer with } \\
\text { all/most of the parts of a travelling experience. }\end{array}$ \\
\hline Very low rate of interactivity. & High rate of interactivity. \\
\hline Very low involvement of shared economy concept. & High rate of shared economy concept involvement. \\
\hline $\begin{array}{l}\text { Limited options to manage a travelling experience } \\
\text { online. }\end{array}$ & Almost everything can be handled online. \\
\hline
\end{tabular}

Figure 2: Differences between Tourism and Smart Tourism

\section{CLASIFICATION OF SMART TECHNOLOGY IN TOURISM}

Smart technology used in tourism has not been categorized yet. We divided it into several categories, which enable companies to better identify customers' needs and expectations.

- Websites and web portals. The main reason which enables an existence of smart technology and its use in tourism is an internet connection. And the most basic smart technology available are websites which usually provide information about destination, city or specific attraction. The second type of websites is a portal, which enables its users to interact and e.g. plan a trip, book an accommodation, rent a car or buy a flight ticket.

- Mobile applications. Mobile applications are often based on the website and their purpose is to make a whole online procedure simpler and faster. Some of the applications, however, do not have a web basis and are available only in the form of an application. Purpose of applications is similar as by websites, moreover they should strengthen the travelling experience by user interaction and geolocating.

- Portable audio and video devices. These gadgets usually do not require the use of customer's own device, although in some cases they can be already integrated in an application. The typical example of these portable audio and video devices are city guides with audio/video commentary which a trip organizer lends their customer for a specific period of time.

- Smart infrastructure. These tools can be considered in two different "smart areas" - smart tourism and smart cities. Their main purpose is to act as a help for tourists (usually maps or interactive info totems) or as a space for advertisement, but all visually compliant with the surroundings. Another example is smart bench which runs on solar energy generated in built-in solar collectors and provides a space for video-presentation and possibility to e.g. charge the phone. Other examples are wireless network (Wi-Fi) or shared economy tools, such as bike sharing, carsharing or flat sharing.

- Augmented reality systems. Typical examples of augmented reality systems are holograms or a virtual reality device, which enables the customer to travel without any physical transportation.

- Integrating smart solutions. Smart solutions, which purpose is to create an integrated touristic system, e.g. of transport, attractions and sightseeing or entertainment and shopping. Typical example is a city loyalty discounts program. 


\section{SMART TOURISM IMPLEMENTATION IN BRATISLAVA, SLOVAKIA}

Bratislava, as the capital of Slovak republic, is the biggest and at the same time the most visited Slovak city. Based on Bratislava Tourist Board's (hereinafter as 'BTB') data, the annual count of Bratislava visitors increased during the 9 years (2008 - 2016) by more than $60 \%$. [7]

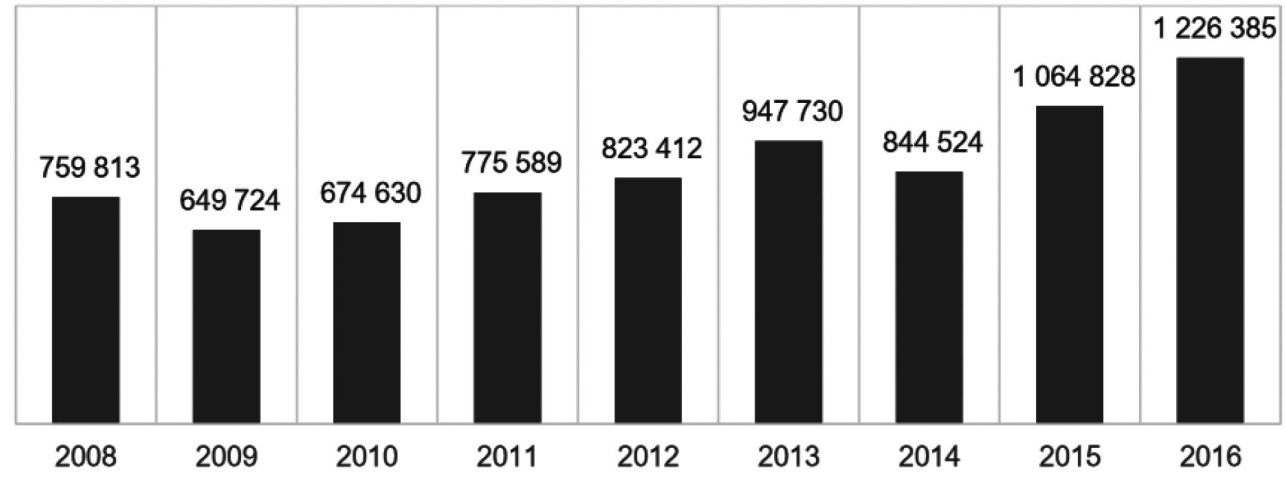

Figure 3: Annual Count of Bratislava Visitors (2008 - 2016) [7]

These numbers provide an opportunity to increase them even more. 'BTB' is aware of this fact and has already started to implement several smart solutions to the city infrastructure.

Bratislava currently runs two main websites. Bratislava.sk aims at local inhabitants and tries to make their everyday citizens' life simpler. On the other hand, target group of visitbratislava.com is different. This website provides domestic and foreign tourists with basic historical, geographical, cultural and artistic information and should act as a background when planning a trip.

Several mobile applications are related to Bratislava. An official one is called Bratislava, has more than 10,000 downloads and is, more or less, simplified version of visitbratislava.com website. It can be used offline and provides the user with travelling tips, main city attractions, events, restaurants or transport. Besides this one, Bratislava is the main topic of several other apps concerned about bike sharing, sightseeing or transportation.

Portable audio and video devices are mainly part of third-party mobile applications. By city tours, Bratislava prefers human guides, what makes the touristic experience more interactive and personalized, although some private agencies also offer portable audio guides.

Several smart benches and interactive touchscreen info totems create smart infrastructure located to create a modern impression and at the same time to help tourists to get the information they want. This is possible also because of free internet connection through Wi-Fi in BTB locations, public transport and in the city centre. Increase in popularity is noticeable in shared economy systems, mainly in Airbnb, Uber or bike sharing. Currently, more than 300 flats or rooms are available for stay in Bratislava and the most popular bike sharing program has now after one year of order more than 41,000 users who have made together more than 220,000 rides. [8]

Several private virtual reality bars are present in Bratislava, however none of them provide their customers with virtual touristic experience yet.

Integrating smart solutions are the main symbol of Bratislava being smart. The Integrated Transport System (ITS) in whole Bratislava region and Bratislava CARD (BC) are its pillars. ITS 
connects public transport and suburban bus and railways transport and enable people to travel with only one common ticket. The purpose of the $\mathrm{BC}$ is to provide tourists with several discounts and free entries or transportation, while its purchasing fee starts only at $18 €$ per 24 hours.

\section{CONCLUSION}

Join of tourism and smart technology seems to have huge potential. Especially in country like Slovakia, which has rich history and tradition of tourism and still a lot to offer. This "smart wave" comes from the USA and the western Europe, but now or later will definitely fully influence the tourism in central- and eastern European countries. And we recommend the companies operating in tourism sector to start to take smart tourism concept into account, because this may be a significant competitive advantage in the future market. And Slovakia, especially Bratislava, is on a good way.

\section{REFERENCES}

[1] Li Y. et al. (2016). The concept of smart tourism in the context of tourism information services. In Tourism management (58). March 14, 2016.

[2] Gretzel, U. et al. (2015). Smart tourism: foundations and developments. In Electron markets (25:179).

[3] Wang, D. et al. (2012). The Role of Smartphones in Mediating the Tourism Experience. In Journal of Travel Research (51/4).

[4] Lopez de Avila, A. (2015). Smart Destinations: XXI Century Tourism. Presented at the ENTER2015 Conference on Information and Communication Technologies in Tourism, Lugano, Switzerland, February 4-6, 2015.

[5] Al Nuaimi, E. et al. (2015). Applications of big data to smart cities. In Journal of Internet Services and Applications 2015.

[6] Hunter, W. C. et al. (2015). Constructivist Research in Smart Tourism. In Asia Pacific Journal of Information Systems (25/1).

[7] Bratislava Tourist Board (2017). Marketingová a komunikačná stratégia destinácie Bratislava 2018 - 2022.

[8] Bratislavské noviny (2019). Za používanie Slovnaft BAjku sa bude od 1. apríla platit' viacna kol'ko vás vyjde jedna jazda? [online] [cited June 19, 2019]. Available at: $<$ https://www. bratislavskenoviny.sk/aktuality/bratislava/54098-za-pouzivanie-slovnaft-bajku-sa-budeod-1-aprila-platit-na-kolko-vas-vyjde-jedna-jazda> 